\title{
Need Analysis in Development of Teaching Factory In Higher Education
}

\author{
Tri Murwaningsih ${ }^{1}$, Subroto Rapih ${ }^{1}$ \\ 1 Faculty of Teacher Training and Educations Sebelas Maret University \\ Email: subrotorapih@gmail.com
}

\begin{abstract}
Open Unemployment Rate (TPT) for undergraduate (S1) actually experienced a significant increase. Recorded Bachelors unemployment rate increased from 5.34 percent in February 2015 to 6.22 percent in February 2016. Thus a strategic step is needed to align the world of education and the world of work. One of the steps that is considered most appropriate is to carry out Teaching Factory activities in colleges. The purpose of this study are: 1) Identify the need for the University in the implementation of Teaching Factory. 2) Mapping the constraints faced by the University in the implementation of Teaching Factory. The chosen research approach is a qualitative method utilized to answer the research problem. Data collection techniques were conducted through in depth interview, focus group discussion (FGD), observation, and document analysis. Analysis data used interactive analysis model Miles and Huberman. The results of this research are: 1) The main needs of Univerisity in performing Teaching Factory activities are the availability of expertise-based curriculum and partner industry in accordance with the field of expertise. 2) Constraints faced by universities in Teaching factory activities are availability of facilities and infrastructure and difficulties in obtaining appropriate partner industry.
\end{abstract}

\section{Keywords: teaching factory; model; higher educations}

\section{INTRODUCTION}

Universities which is the highest educational institution to date has not been able to respond to changes that occur in the world of work. Central Bureau of Statistics (BPS) reported open unemployment rate (TPT) in February 2016 was recorded at 5.5 percent. This means that from 100 labor force there are about five to six unemployed people. When compared to the previous period ie February 2015, TPT decreased by 0.31 percent. However, TPT for university graduates or undergraduate (S1) actually experienced a significant increase. Recorded Bachelor's unemployment rate increased from 5.34 percent in February 2015 to 6.22 percent in February 2016. The fact is quite surprising that universities should be able to provide sufficient supplies to their graduates so that college graduates are able to enter the workforce.

Based on the results of the study of global consulting agency Willis Towers Watson about Talent Management and Rewards revealed, since 2014 eight of ten companies in Indonesia difficulty getting college graduates ready to use. In other words, the number of university graduates is unemployed due to the inequality between the profile of university graduates with the qualifications of the ready-made 
labor required by the company. Still according to the study results, the growth rate of college graduates in Indonesia every year is always increasing. Meanwhile, the number of companies demand for labor is always lower than the number of graduates. The above phenomenon indicates that there must be a fundamental change in the education system in universities in order for the university to return to its marwah as an institution that produces graduates who are ready to enter the world of work.

One step that could be an alternative to align the world of education with the industrial world is the teacing factory program. Teaching factory can simply be interpreted as the opposite of an apprenticeship program. If the student apprentices program that goes into the industry then in the teaching program of the industrial world is what goes into the world of education.

Karen Wilson of the European Foundation for Entrepreneurship Research entitled "Entrepreneurship Education in Europe (2008)" describes the concept of teaching factory as an Academic-Business Links, in which there is a relationship between the university and the entrepreneur. The relationship is not merely networking alone, but involving them in the process of teaching in the classroom. In some countries such as Britain, Ireland and Spain, they play a more active role in engaging local business communities and alumni. This approach was originally pioneered by colleges in the United States. They involve successful entrepreneurs and talk in front of the students about entrepreneurship education. It aims to combine experience in the world of work as well as their involvement in various projects.

Teaching factory allows the industry to enter the world of education to provide a real activity based on industry activities. The basic principle of teaching factory is the integration of the work experience into the school curriculum. All equipment and materials and educational actors are structured and designed to perform the production process in order to produce products (goods or services) [1]. Teaching factory activities allow students to learn to do industrial activities with guidance from partners who come from the industrial world. This activity allows for deeper skill transfer because students directly perform an industry activity that they manage and manage independently.

Based on the background of problems as described above, this study has a general purpose of identifying the needs and constraints faced in the implementation of teaching factory in Higher Education (Education Studies Program Administration Office).

\section{LITERATURE REVIEW}

\section{Teaching factory}

The basic concept of teaching factory is the integration of work experience into the school / college curriculum. All equipment and materials and educational actors are prepared and designed to perform the production process in order to produce products (goods or services) [1]. Sudiyanto [2] in his research stated that, teaching factory is a learning activity by doing production activities either in the form of goods or services within the school education environment by students. Goods or services generated in teaching factory activities should have a selling point and worthy to be marketed to consumers. 
Learning factory is a combination of competency-based learning with productionbased learning. Herminarto [3] explains that competency-based learning emphasizes the achievement of the competence of learners. Competence of learners can be achieved through learning: (1) student-centered (student active learning); (2) learning by doing (learning by doing); (3) develop intellectual, emotional, spiritual, and social intelligence; (4) independent learning and learning to work together. So that learning factory activity is an integeration of competency-based learning with productionbased learning.

Based on the theory that has been described above, learning factory is a combination and synchronization between the world of education and industry, teacing factory mengedapankan two important specs are competency-based learning and production-based learning. Learners are given a real learning experience by presenting a production environment in learning.

\section{The purpose of teaching factory}

Hadlock, Wells, Hall, Clifford, Winowich, and Burns [4] reveal that teaching factory has the goal to make students realize that teaching should be more than just what is in the book. The learning that is supposed to go to a more advanced level is "doing" not just at the "listening" and "seeing" levels. In accordance with the principle of teaching factory implementation, the concept of production environment to produce goods or services must be presented in the world of education. The purpose of that is, so that learners have a learning experience as well as experience in the world of work.

In line with the previous opinion Moerwismadhi [5] revealed that in teaching factory, schools carry out production activities or services that are part of the teaching and learning process. Thus the school is required to have a factory, workshop or other business unit for learning activities.

The purpose of the most essential teaching teaching activity is to bring a real learning experience to the learners. Such learning will be very useful in the context of hard skills training and soft skills for learners. Hard skills will be obtained from the production activities they perform while soft skills will be obtained from the cooperation and sense of responsibility that they get from the production activities that they actually manage and management independently with guidance from the school and industry.

\section{Synergy between government, education and industry}

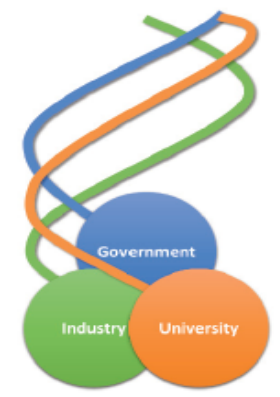

Figure 1. Triple helix model University,Industry, Government [6] 
Teaching factory is a derivative of the concept of link and match that has been long enough encouraged. Due to still in the big house the concept of link and match then the teaching factory is in need of cooperation and collaboration from 3 sectors of education, industry and government. The synergy of the three sectors is indispensable in the successful implementation of teaching factory.

The synergy between government, education and industrial dnia is also known as the triple helix model. In this collaboration, the government has a role to facilitate between education and industry in establishing cooperation. In addition, the government as a stakeholder also plays a role in the issuance of laws and regulations and the provision of facilities in support of the implementation of the teaching factory program. The world of education has a role to pro actively cooperate and improve the quality of service for pogram teaching factory derjalan smoothly. While the world of industry has a role in guiding and establishing cooperation with the world of education.

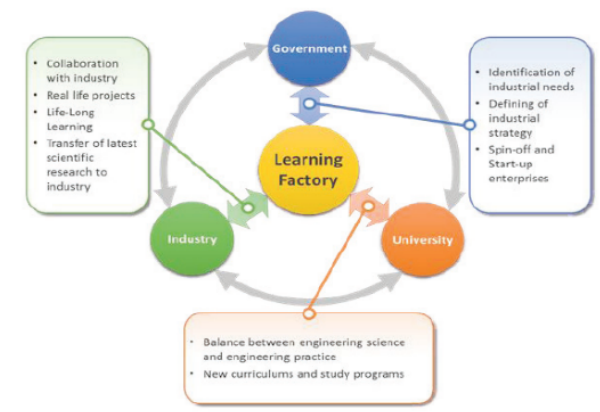

Figure 2. Learning Factory as a missing link in Triple helix model [7]

The teaching teaching position is right between the three relationships between government, education and industry. Teaching factory can be regarded as the link of the cooperative relationship.

\section{METHOD}

This research uses qualitative research model. Qualitative research aims to obtain a complete picture of a thing according to the views of the human being studied. Qualitative research is related to the ideas, perceptions, opinions, or beliefs of the people studied; All of which can not be measured by numbers [8]. Qualitative research is generally designed to provide a real experience and capture the meaning as created in the field of research through direct interaction between researchers and researchers [9]. The sampling technique used is purposive sampling, where the individual who becomes the informant in the study is chosen because it meets certain criteria or objectives of the researcher eg consideration based on the theoretical concept used, the researcher's personal curiosity, empirical characteristics and others. [10].

Data collection techniques in this research are: Focus Group Discussion (FGD), interview, observation and document analysis. Data analysis techniques use interactive analysis model [11]. In this analysis model consists of data collection, data reduction, data presentation and conclusion / verifications. 


\section{Results and discussions}

In the development of teaching factory implementation model, there are predevelopment steps in the form of needs analysis and constraint analysis encountered in the model development process. The steps are arranged systematically to get results that match the needs of the model to be generated.

\section{Curriculum analysis}

Curriculum analysis is the first step in the preparation of teaching factory model in Prodi PAP. Curriculum analysis is conducted to adjust between courses possible to synchronize with the world of activity in the industrial world. Curriculum Prodi PAP is now in accordance with the Indonesian National Qualification Framework (KKNI) standards so that for the development of the curriculum is very wide open.

The PAP curriculum consists of 152 credits (63 subjects) with compulsory subjects of 138 credits ( 57 subjects), 14 credits ( 7 courses) elective courses, but the student can only take a maximum of 6 credits. While the courses are equipped with practicum as much as 24 credits (10 courses). 63 subjects are divided into 5 groups of subjects based on SK Kemendiknas Number 045/U/ 2002, namely:

Table 1. group of course

\begin{tabular}{|clc|}
\hline No. & \multicolumn{1}{c|}{ Group of courses } & Quantity \\
1. & Personality Development Course (MPK) & 9 course. \\
2. & Scientific and Skill Course (MKK) & 6 course \\
3. & Skills Courses (MKB) & 44 course \\
4. & Course of Working Behavior (MPB) & 7 course \\
5. & Community Lecture Course (MBB) & 7 course \\
\hline
\end{tabular}

The number of credits (minimum for graduation) is 144 credits composed of 2 types of subjects: compulsory subject and elective courses.

Table 2. course type

\begin{tabular}{|c|c|c|}
\hline Course Type & Credits & Explanations \\
\hline Compulsory & 138 & The compulsory courses are spread from \\
\hline Courses & & semester 1 to semester 8 \\
\hline Elective courses & 6 & $\begin{array}{l}\text { In the curriculum there are } 7 \text { elective courses } \\
\text { each consisting of } 2 \text { credits. This elective course is } \\
\text { in semesters } 5,6 \text { and } 7 \text {. At least } 3 \text { elective subjects } \\
\text { must be selected by students and organized by the } \\
\text { study program. For academic year } 2014 / 2015 \text {. }\end{array}$ \\
\hline Total & 144 & \\
\hline
\end{tabular}

Based on the structure of the curriculum it is seen that the practice course has a considerable portion that is visible from the course of expertise of work with the number of 44 courses. Quite a lot of courses of expertise work is an important capital in the development of teaching factory because in these courses are taught about skill-skill that is in accordance with the scope of work of partner industry.

Courses such as Computer Administration 1 and 2, office technology, office machine technicians, computer graphics and web programming are the main courses 
that provide expertise to support the ongoing teaching factory activities. The material structure and discussion in the course are tailored to the character of the partner industry to be invited to cooperation.

The curriculum is a major factor in designing a model of teaching factory implementation because in that curriculum, students or students get the keenness and competence that will be aligned with the competencies of the partner industry. Curriculum Prodi Education Administration Office FKIP UNS very supportive in the development of teaching factory activities. The findings are at least based on 2 things. First, the curriculum of PAP Program FKIP UNS has been in accordance with KKNI and based on competence. So that the curriculum is very possible to be developed further in the form of improvements of learning activities and other innovations aimed at improving the competence of learners. Secondly, the current curriculum structure that contains practice-based courses has a sufficient portion so that it will be easier in aligning learning with partner industry in the form of teaching factory activities.

\section{Analysis of facilities and infrastructure}

Facilities and infrastructure are very important in the implementation of teaching factory activities. Teaching factory activities based on the principles of collaboration and cooperation require both parties (educational institutions and industry) have a role in a balanced portion so that a good and mutually beneficial cooperation. Facilities and infrastructure is a basic need for both parties, especially for educational institutions that will carry out teaching activities. Educational institutions that will host activities must prepare adequate and representative facilities and infrastructure to support activities. Based on the study, PAP FKIP UNS has adequate infrastructure.

Table 3. list of insfrastructure

\begin{tabular}{|clcc|}
\hline No. & \multicolumn{1}{c}{ Insfarstructure } & Units & Total are $\left.\mathbf{~ ( m ~}^{\mathbf{2}}\right)$ \\
1 & Ruang Kuliah & 5 & 270 \\
2 & University library & 1 & 2000 \\
3 & Reading room & 1 & 16 \\
4 & Laboratorium Mini Office & 1 & 72 \\
5 & Laboratorium MICE & 1 & 30 \\
6 & Laboratorium office technology & 1 & 24 \\
7 & Laboratorium IT & 2 & 96 \\
8 & Laboratorium Micro Teaching & 2 & 40 \\
9 & Laboratorium manual typewriter & 1 & 40 \\
10 & Laboratorium Bahasa & 3 & 144 \\
\hline
\end{tabular}

Based on the above table, the infrastructure is complete enough to support the learning activities. The next step is to conduct supporting infrastructure analysis for the implementation of teaching factory activities. In accordance with the principle of teaching factory activities, infrastructure criteria that can support teaching factory activities that is able to support productive activities.

Based on the above criteria then selected some infrastructure that is able to support the activities of teaching factory activities. These include: 
Table 4. list infrastructure that able to support the activities of teaching factory activities

\begin{tabular}{|clc|}
\hline No. & \multicolumn{1}{c|}{ Infracstructure } & Units \\
1 & Laboratorium MICE & 1 \\
2 & Laboratorium Teknologi Perkantoran & 1 \\
3 & Laboratorium TIK & 2 \\
\hline
\end{tabular}

The results of the study of each infrastructure that is able to support the teaching teaching activities are:

a) MICE laboratory

MICE as a tourism activity whose activity is a combination of leisure and business, usually involves a group of people together, a series of activities in the form of meetings, incentive travels, conventions, congresses, conferences and exhibition. MICE Laboratory of PAP FKIP UNS is sufficient to support cooperation with industry partners. Selected industrial partners are engaged in the hospitality department so as to match the capabilities and expertise of PAP students about the MICE industry sector.

b) Office Technology Laboratory (TP)

The TP Laboratory gives knowledge and understanding to potential HR candidates AP How to record, assemble, process, reproduce, transmit and store information materials efficiently using machines. Laboratory of TP Prodi PAP has sufficient equipment for cooperation activities with industrial partners. The industrial partners that are planned to support teaching factory activities come from the printing and publishing services sector.

c) ICT Laboratory

ICT laboratories are flexible enough to work with partner industries. The availability of computer devices and specifications is quite high. An election plan for industrial partners that matches the students' capabilities and availability of infrastructure will be selected by industry partners from the graphic design and digital printing sectors.

\section{Analysis of industrial partners}

An industry partner that will work with an educational institution is an absolute requirement for teaching classroom activities. Needs analysis to determine industry partners is needed to adjust the capabilities and needs of educational institutions. Needs analysis for industrial partners is done with several approaches. Among others:

a) Network of graduates

graduates have very important role in determining industry partners. The wellestablished network of Prodi PAP alumni is one way to determine the partner industry. From the alumni network search results, it is known there are some alumni who currently have become entrepreneurs in the field of hospitality services and tourism bureau. Focus Group Discussion (FGD) by inviting 12 narasubers from alumni with business background namely hospitality, tour and culinary bureau.

Based on the FGD conducted, the business field of hospitality and tourism bureau is the most likely business field to be an industrial partner by paying attention to the availability of student's infrastructure and expertise which is gained in 
lecturing process. As for the culinary business is not selected due to lack of in accordance with the availability of infrastructure and student abilities in accordance with the field of science office administrations.

Hospitality and tourism bureaus are projected to be deployed in MICE activities which are viewed from the aspect of the readiness of the infrastructure and the ability of the university students sufficient. The partner of industry in this case acts as partner and supervisor of Prodi PAP students in doing teaching factory activities. In accordance with the principle of teaching factory activities, partner industry stakeholders will delegate projects on MICE activities to PAP students to work on. Due to the still in development stage, the partner industry will still conduct assistance activities during the activity with the note still provide flexibility for PAP students to manage and run the project.

b) Cooperation with the Chamber of Commerce and Industry (KADIN) of Suarakarta Municipality

Need analysis with industrial partners is also done by conducting FGD with KADIN of Suarakarta City. Representatives from KADIN are represented from industry partners engaged in printing, digital printing, design, publishing and repairing computers. Full FGD Participants from industry parties can be seen in the table below:

Table 5. FGD Participants from KADIN

\begin{tabular}{|c|c|c|}
\hline No. & Type of business & Quantity \\
\hline 1. & Printing & 1 \\
\hline 2. & Digital printing & 2 \\
\hline 3. & Computer repair & 2 \\
\hline 4. & Publisher & 2 \\
\hline 5. & Design & 2 \\
\hline
\end{tabular}

Based on FGD results, it is determined that the most suitable industrial partners for Teaching factory learning. Selected industrial partners are design, digital printing and computer repairs. The choice of business field is tailored to the ability and support of infrastructure owned by students of PAP Program.

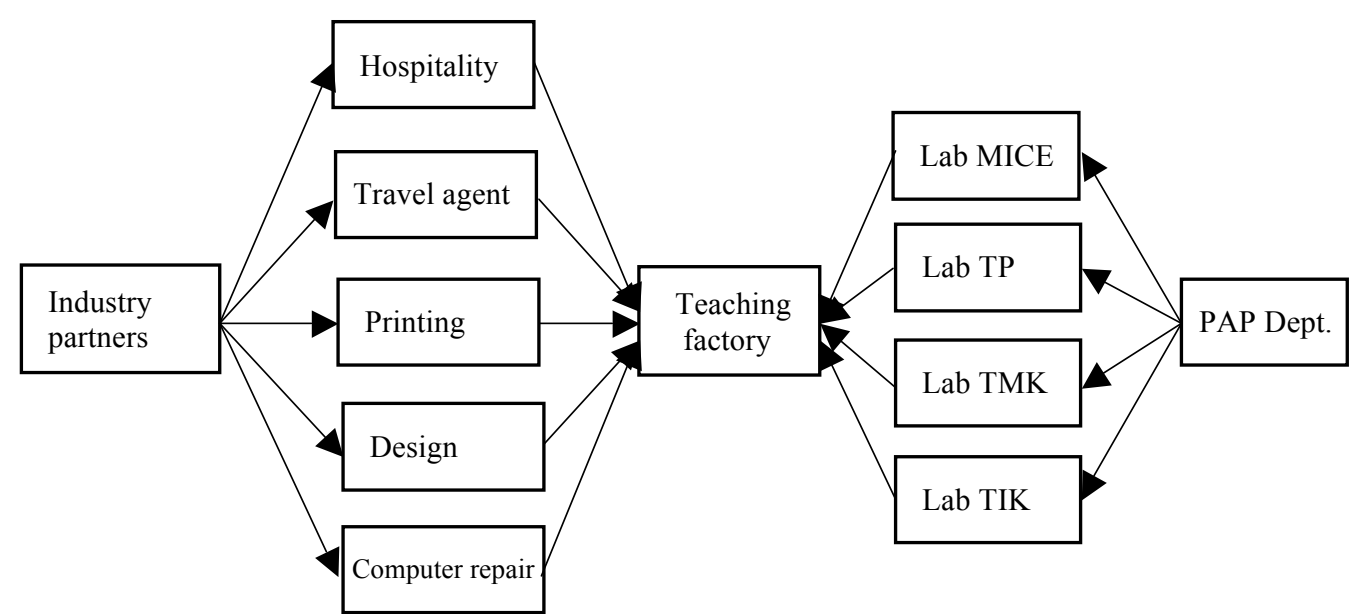

Figure 3. Collaboration between industry partners and office administrations departement 
These partners will be adjusted and synchronized with the expertise and infrastructure owned by Prodi PAP. The students' skills are consistent with computer graphics courses, web programming, office machine technicians and learning technologies. The infrastructure produced by Prodi PAP is also in line with industry partners such as computer laboratories, office technology laboratories and office machine technicians.

\section{CONCLUSIONS}

The development of the teaching factory implementation model begins the predevelopment step in the form of needs analysis and constraint analysis encountered in the model development process. The steps are arranged systematically to get results that match the needs of the model to be generated.

1) Curriculum analysis

Curriculum Prodi PAP FKIP UNS has been in accordance with KKNI and competency-based. So that the curriculum is very possible to be developed further in the form of improvements of learning activities and other innovations aimed at improving the competence of learners. The current curriculum structure that contains practice-based courses has a sufficient portion so that it will be easier in aligning learning with partner industry in the form of teaching factory activities.

2) Analysis of facilities and infrastructure of Prodi PAP FKIP UNS.

The results of the study of each infrastructure that is able to support the teaching teaching activities are:
a) MICE laboratory
b) Office Technology Laboratory (TP)
c) ICT Laboratory

3) Analysis of industrial partners

Needs analysis for industrial partners is done by two approaches. Among others:

a) Network of graduates

Hospitality and tourism bureau become the most suitable alternative to collaborate with partners Prodi PAP. Both industrial partners are projected to be deployed in MICE activities which viewed from the aspect of the readiness of the infrastructure and the ability of university students sufficient.

b) Cooperation with the Chamber of Commerce and Industry (KADIN) of Suarakarta Municipality

Selected industrial partners are design, digital printing and computer repairs. The choice of business field is tailored to the ability and support of infrastructure owned by students of PAP Program. These partners will be adjusted and synchronized with the expertise and infrastructure owned by Prodi PAP. The students' skills are consistent with computer graphics courses, web programming, office machine technicians and learning technologies. The infrastructure produced by Prodi PAP is also in line with industry partners such as computer laboratories, office technology laboratories and office machine technicians. 


\section{REFERENCES}

[1] Lamancusa, J. S., Jorgensen, J. E., Zayas-Castro, J. L., \& De Ramirez, L. M. (2001, August). The Learning Factory-Integrating Design, Manufacturing and Business Realities into Engineering Curricula-a Sixth Year Report Card. In International Conference on Engineering Education (pp. 6-10).

[2] Sudiyanto, G.S., Yoga, S., Ibnu. (2011). Teaching factory di SMK ST. Mikael Surakarta. Fakultas Teknik Universitas Negeri yogyakarta.

[3] Herminarto, Sofyan. (2008). Optimalisasi Pembelajaran Berbasis Kompetensi pada Pendidikan Kejuruan. Pidato Pengukuhan Guru Besar, disampaikan pada Rapat Terbuka Senat Universitas Negeri Yogyakarta, Sabtu 16 Februari 2008.

[4] Hadlock, H., Wells, S., Hall, J., et al. (2008). From Practice to Entrepreneurship: Rethinking the Learning Factory Approach. Proceedings of The 2008 IAJC-IJME International Conference, ISBN 978-1-60643-379-9.

[5] Moerwismadhi. (Agustus 2009). Teaching factory Suatu Pendekatan dalam Pendidikan Vokasi yang Memberikan Pengalaman ke Arah Pengembangan Technopreneurship. Makalah disajikan dalam Seminar Nasional Technopreneurship Learning For Teaching factory, di Malang Jawa Timur.

[6] Etzkowitz, H. (2002). The triple helix of university-industry-government: implications for policy and evaluation. Swedish Institute for Studies in Education and Research.

[7] Veza, I., Gjeldum, N., \& Mladineo, M. (2015). Lean learning factory at FESB-University of Split. Procedia CIRP, 32, 132-137.

[8] Sulistyo-Basuki. 2006. Metode Penelitian. Jakarta: Wedatama Widya Sastra dan Fakultas Ilmu Pengetahuan Budaya Universitas Indonesia

[9] Pendit, Putu Laxman. 2003. Penelitian Ilmu Perpustakaan dan Informasi: Suatu pengantar Diskusi Epistimologi dan Metodologi, Jakarta: JIP-FSUI

[10] Daymon, Christine., dan Immy Holloway. 2008. Metode-metode Riset Kualitatif: dalam Public Relations dan Marketing Communications. Yogyakarta: Penerbit Bentang.

[11] Miles, Matthew dan Huberman, A. Michael. 1992. Analisis Data Kualitatif: Buku Sumber Tantang Metode-Metode Baru. Jakarta:UI Press. 